\title{
Історія вивчення мошок Українських Карпат
}

Проаналізовано сучасний стан вивчення мошок Українських Карпат. Установлено, що дослідження Simuliidae регіону тривають понад 60 років. 3'ясовано, що значний внесок у вивчення мошок у 60 -ті роки ХX ст. зробили В. З. Ковбан і Г. К. Шевченко, а починаючи з 70-х - 3. В. Усова, О. Б. Панченко, А. О. Панченко, К. Б. Сухомлін. Згідно з останніми даними К. Б. Сухомлін, симуліїдофауна Українських Карпат нараховує 45 видів із 14 родів.

Ключові слова: мошки, фауна, видовий склад, кровососи, Українські Карпати.

Постановка наукової проблеми та їі значення. Мошки (Diptera: Simuliidae Newman, 1834) родина комах, роль яких у природі й житті людини загальновідома ще з минулого століття [21]. Насамперед, вони мають важливе медико-ветеринарне значення, оскільки самки більшості видів $€$ активними кровососами, що завдають значних збитків сільському господарству, знижуючи продуктивність тварин та праці людей, і переносниками збудників багатьох небезпечних захворювань (онхоцеркоз й анаплазмоз великої рогатої худоби, філяріоз, гемоспоридіоз, лейкоцитозооноз та трипанозомоз птахів) $[2,3]$. Крім того, мошки на різних фазах розвитку - важливі структурні ланки багатьох трофічних ланцюгів: преімагінальними фазами живляться личинки багатьох водних комах і риб, а дорослими - комахоїдні птахи й деякі земноводні $[10,14,15,21]$.

Територія Українських Карпат має щільну гідрологічну сітку та розміщена в помірно континентальному кліматі, що створює сприятливі умови для масового виплоду симуліїд. Тому питання дослідження цієї групи комах у регіоні має велике як теоретичне, так і практичне значення.

Аналіз досліджень цієї проблеми. Спеціальні узагальнюючі праці, у яких здійснено огляд літературних відомостей щодо вивчення мошок Українських Карпат, до цього часу не публікувалися. Короткі положення та замітки знаходимо лише в окремих роботах $[5,23]$, де науковці зазвичай подають кількісні показники видового складу симуліїд.

Мета й завдання статті - 3'ясувати сучасний стан вивчення мошок Українських Карпат, проаналізувати видове різноманіття та вияснити, які з аспектів їхньої життєдіяльності розкриті неповно $\mathrm{i}$ $€$ перспективними для подальшого вивчення.

Виклад основного матеріалу й обгрунтування отриманих результатів дослідження. Вивчення мошок Українських Карпат розпочалось із середини XX ст. із робіт Ханса Яановича Ремма [20]. У літературі цього періоду знаходимо лише фрагментарні відомості про поширення, деякі аспекти біології й екології окремих видів, що відзначені в рамках цієї території.

Грунтовні відомості щодо симуліїд, зокрема й території України, знаходимо в роботах Івана Антоновича Рубцова [21], який відзначає в межах нашої держави 21 вид із 12 родів. Указуючи географічне поширення, науковець зазначив деякі види мошок, що трапляються в Українських Карпатах.

Подальше вивчення симуліїд у 60-ті роки XX ст. пов'язане з науковою діяльністю Віталія Захаровича Ковбана та Ганни Кіндратівни Шевченко. Більшість праць В. З. Ковбана розкривають медико-ветеринарне значення кровосисних видів мошок передгірної частини й частково гірської системи Карпат у межах Львівської й Івано-Франківської областей. Зокрема, науковець акцентує увагу на захворюваності сільськогосподарських тварин унаслідок масових покусів мошок - симуліїдотоксикозі [3] та онхоцеркозі великої рогатої худоби, пропонуючи систему оздоровчих заходів проти цього захворювання [2]. Також учений розглядає питання зниження чисельності преімагінальних фаз мошок у проточних водоймах регіону за допомогою використання спеціальних хімічних препаратів - нікохлорану й поліхлорпілену [4]. В. З. Ковбан, окрім того, досліджував біологію симуліїд. В одній зі своїх праць [1] він повідомив, що активними кровососами передгірної частини Карпат є сім видів мошок. Пік їх активності припадав на вранішні (8-9 год) і вечірні (18-20 год) години при температурі повітря близько $20^{\circ} \mathrm{C}$ і відсутності вітру. Перші яйцекладки дослідник спостерігав у кінці квітня, а максимальну активність самок мошок відзначив у червні-липні на ділянках території поблизу місць виплоду цих комах.

Г. К. Шевченко [26] вперше зробила спробу підсумувати результати 10-річних досліджень симуліїдофауни України. В Українських Карпатах науковець відзначила 11 видів із восьми родів:

(C) Теплюк А., 2016 
Prosimulium hirtipes Fries, 1824, Cnephia pallipes Fries, 1824, Eusimulium angustitarse Edwards, 1915, Obuchovia auricoma Meigen, 1818, Boopthora erytrocephala De Geer, 1776, Friesia condici Baranov, 1926, Odagmia variegata Meigen, 1818, Simulium morsitans Edwards, 1915, Simulium argyreatum Meigen, 1838, Simulium galeratum Edwards, 1920, Simulium vulgare Rubzov, 1940.

Систематичне й комплексне вивчення мошок Українських Карпат розпочалось у 70-х роках минулого століття. У літературі цього періоду з'являються перші відомості працівників Донецького університету Олександра Борисовича Панченка та Зінаїди Василівни Усової щодо мошок Закарпатської області [25]. Дослідники зареєстрували 42 види кровосисних симуліїд, що належать до дев'яти родів: $P$. hirtipes, $P$. vigintiquaterni Enderlein, 1929, $P$. duodecimfiliatum Rubzov, 1955, E. latipes Meigen, 1804, E. costatum Fried, 1920, E. tauricum Rubzov, 1956, E. brevidens Rubzov, 1956, E. bertrandi Grenier \& Dorier, 1959, E. sp. ex gr. angustitarse, E. sp. ex gr. aureum Fries, 1824, E. latigonium Rubzov, 1956, E. securiforme Rubzov, 1956, E. codreanui Serban, 1958, Wilhelmia equina Linnaeus, 1758, W. mediterranea Puri, 1925, W. salopiensis Edwards, 1927, W. balcanica Enderlein, 1924, Ob. auricoma Meigen, 1818, Ob. brevifilis Rubzov, 1956, B. erytrocephala, Gnus rostratum Lundström, 1911, Od. ornata Meigen, 1818, Od. ornata nitidifrons Edwards, 1921, Od. frigida Rubzov, 1940, Od. baracornis Baranov, 1926, Od. variegata, Od. sp. ex gr. monticola Fried, 1920, Od. maxima Knoz, 1961, Od. reophila Knoz, 1961, Tetisimulium bezzi Corti, 1914, T. condici Baranov, 1926, S. sp. ex gr. tuberosum Lundström, 1911, S. vulgare, S. argenteostriatum Strobl, 1900, S. truncatum Lundström, 1911, S. morsitans, S. argyreatum, S. reptans Linnaeus, 1758, S. galeratum, S. schönbaueri Enderlein, 1920, S. degrangei Dorier et Grenier, 1959, S. voilense Serban, 1958 [25]. Вони класифікували водойми регіону, у яких розвиваються мошки. Для кожного з п'яти встановлених типів водойм подано коротку характеристику (указано тип дна, швидкісь течії, середню температуру води, наявність рослинності) і наведено видовий комплекс симуліїд, що притаманний для них: у великих річках розвивається шість, у середніх річках - 10 , у малих -21 , у малих річечках із швидкою течією - 16, у струмках -23 види. О. Б. Панченко й 3. В. Усова також вивчали фауну та біологію мошок, природоохоронних територій, зокрема Карпатського заповідника [17]. Вони повідомили, що в річці Біла Тиса, іiї притоках і струмках розвиваються 15 видів мошок із п'яти родів.

Вивченням мошок Передкарпаття займався Альфред Олексійович Панченко. Він зареєстрував 42 представники симуліїдофауни регіону та здійснив зоогеографічний аналіз [7]. Особливу увагу приділено видовому складу мошок верхнього басейну Дністра й Пруту, що розміщені в межах гірської системи [6].

У 80-ті роки грунтовні дослідження родини Simuliidae продовжував О. Б. Панченко. Він повідомив, що в Закарпатській області кровососами є 11 видів та один підвид симуліїд: P. hirtipes, W. equina, W. salopiensis, W. mediterranea, B. erytrocephala, B. sericata Meigen, 1830, Od. ornata, Od. variegata, S. morsitans, S. reptans, S. reptans var. galeratum, S. voilense. Науковець прослідкував трофічні зв'язки симуліїд регіону [14], установив активність нападу й з'ясував місця схованок імаго [18]. О. Б. Панченко відзначив, що мошки нападають переважно на сільськогосподарських тварин, іноді - на людину. Їхня активність починається з другої декади травня та продовжується до третьої декади вересня. Сезонний хід чисельності самок, які нападають, характеризується двома піками: весняним - у третій декаді травня й літнім - у третій декаді червня; оптимальними при цьому є температура в межах $16-25^{\circ} \mathrm{C}$, освітленість - 1000-20 000 люкс та швидкість вітру до $2 \mathrm{~m} / \mathrm{c}$. Літ імаго зазвичай закінчується до 21 год. У нічний час місцями схованок для мошок були крони дерев листяних порід, нижня сторона великих каменів на схилах гір, де відсутні дерева, стіни із затишного боку під навісами сільськогосподарських будівель. У жаркий період доби імаго ховалися на нижній стороні прикореневого листя підбілу, лепехи та в листі ліщини.

Крім того, О. Б. Панченко вивчав популяційну й екологічну мінливість ознак личинок на прикладі Boophtora erythrocephala у водотоках Закарпаття [16]. Науковець порівняв популяції личинок гірської холодноводної річки Чорна Тиса та передгірної річки 3 теплішою водою - Іршави - і повідомив, що різні умови їх існування визначають мінливість морфологічних структур. За його даними, найменш мінливими ознаками були ширина та розміри субментума та мандибули, а найбільш варіюючими - кількість щетинок на премандибулі, рядів гачків в органі прикріплення. Мінливість меристичних ознак виду за коефіцієнтом варіації склала 4,3-11,7 \%. 
Під час дослідження особливостей зимівлі симуліїд у межах Закарпатської області О. Б. Панченко зареєстрував 45 видів мошок. Він указав, що у фазі личинки зимує 15 видів, а решта - у фазі яйця. Науковець повідомив, що в грудні-лютому личинки мігрують у більш глибокі ділянки водойм, їх ріст і розвиток уповільнені. Він зауважив, що заляльковування в низинній частині відбувається в другій декаді березня, а виліт імаго - у другій декаді квітня, тоді як у гірських районах ці процеси проходять пізніше через низьку температуру води [13].

Потрібно зауважити, що наукові дослідження О. Б. Панченка не обмежувалися лише територією Закрпаття, а проводилися на всій території Українських Карпат. Науковець зосередився на вивченні впливу різних видів паразитів і природних ворогів на динаміку чисельності мошок гірського масиву [10]. Він навів видовий склад мікроспоридій личинок симуліїд і повідомив про рівень ураження мікроспоридіозом [12]. О. Б. Панченко відзначив, що на лялечках мошок паразитує гриб Coelomycidium simulii Debaisieux, 1919. За його даними, із досліджених 20250 личинок симуліїд, 12,2 \% виявились ураженими мікроспоридіями 3 двох родів Plistophora Gurley, 1893 і Thelohania Henneguy, 1892, $21 \%$ - грибом C. simulii, близько $13 \%$ лялечок мошок - водяним кліщем. Як природних ворогів личинок симуліїд О. Б. Панченко [10] відзначив личинок волохокрильців, бабок, деяких водних жуків та риб (форель, харіус). Він зауважив, що на імаго полюють павуки, бабки й комахоїдні птахи. Науковець наголосив, що ці біологічні агенти відіграють значну роль у зниженні чисельності кровосисних мошок.

Підсумовуючи результати багаторічних досліджень, 3. В. Усова [24] подає зональний розподіл видів смуліїд, поширених у межах території України. Згідно з їі відомостями, в Українських Карпатах відзначено 46 видів мошок із 15 родів: Twinnia Stone et Jamnback, 1955 - один, Prosimulium Enderlein, 1906 - три, Cnetha Enderlein, 1921 - дев'ять, Newermannia Enderlein, 1921 - два, Eusimulium Roubaud, 1906 - три, Wilhelmia Baranov, 1921 - три, Obuchovia Rubzov, 1947 - два, Gnus Rubzov, 1940 три, Odagmia Enderlein, 1921 - дев'ять, Tetisimulium Rubzov, 1963 - один, Cleitosimulium Segui \& Dorier, 1936 - один, Paragnus Rubzov \& Yankovsky, 1962 - один, Archesimulium Rubzov \& Yankovsky, 1982 - два, Argentisimulium Rubzov \& Yankovsky, 1982 - один, Simulium Latreille, 1802 - п’ять видів.

В останні роки минулого століття О. Б. Панченко й А. О. Панченко [9] уточнювали видовий склад симуліїд передгірної частини та гірських областей Карпат. Детально вивчали фауну мошок Карпатського біосферного заповідника [8] й розглядали роль личинок симуліїд у живленні личинок волохокрильців як основних біорегуляторів їх чисельності у водотоках [15].

У XXI ст. продовжуються дослідження фауни симуліїд Українських Карпат, однак надруковано лише поодинокі праці. Над проблемою й надалі працюють О. Б. Панченко та А. О. Панченко. Вони навели морфологічний опис і біоекологічні особливості зареєстрованих видів, указали ареали та місця їх знаходження, описали ландшафтне поширення симуліїдофауни регіону [19]. Узагальнивши результати багаторічних досліджень, О. Б. Панченко й А. О. Панченко уточнили видовий склад мошок Українських Карпат. За їхніми даними [5], видове багатство мошок регіону нараховує 56 видів, які належать до 16 родів: Twinnia - один, Prosimulium - чотири, Cnetha - 11, Newermannia - два, Eusimulium - три, Boophthora Enderlein, 1921 - два, Wilhelmia - три, Obuchovia - два, Gnus - один, Odagmia - 10, Tetisimulium - два, Cleitosimulium - один, Paragnus - один, Archesimulium - два, Argentisimulium - один, Simulium - 10 видів. Із них спільними для північного макросклону Карпатських гір і Закарпаття є 50 видів. За 30-річний період наукових досліджень О. Б. Панченка й А. О. Панченка фауна мошок Українських Карпат збагатилася низкою видів: із 42 - у 1973 р. [25] до 56 - у 2004 р. [5]. Проаналізувавши систематичні та синонімічні назви зареєстрованих видів симуліїд, учені вперше для регіону відзначили 21 вид із восьми родів: T. hidroides Novak, 1956, P. latimucro Enderlein, 1925, P. rufipes Meigen, 1830, P. tomosvaryi Enderlein, 1921, B. sericata, C. angustata Rubzov, 1956, C. carpathica Knoz, 1961, C. carthusiense Grenier et Dorier, 1959, C. crenobia Knoz, 1961, C. cryophila Rubzov, 1959, C. verna Macquart, 1826, E. angustipes Edwards, 1915, W. pseudequina Segui, 1921, Od. argyreata Meigen, 1838, Od. pratora Fried, 1921, Od. rotundata Rubzov, 1956, S. paramorsitans Rubzov, 1956, S. posticatum Meigen, 1838, S. promorsitans Rubzov, 1956, S. rubtzovi Smart, 1945, S. verecundum Stone \& Jamback, 1955.

Серед останніх праць потрібно відзначити публікації працівників кафедри зоології Східноєвропейського національного університету імені Лесі Українки. Під час вивчення симуліїд басейну річки Теребля К. Б. Сухомлін, О. П. Зінченко й В. С. Теплюк [22] зареєстрували 14 видів із п’яти родів: 
Cnetha - два, Newermannia - один, Eusimulium - два, Odagmia - сім, Simulium - два види. Домінуючими та найпоширенішими були види роду Odagmia.

Унаслідок ревізії власних зборів і колекційних фондів кафедри зоології Донецького національного університету К. Б. Сухомлін й О. П. Зінченко уточнили, що видове багатство симуліїд Українських Карпат нараховує 45 видів, які належать до 14 родів: Prosimulium - три, Cnetha - дев'ять, Newermannia - два, Eusimulium - три, Boophthora - один, Wilhelmia - три, Obuchovia - один, Gnus два, Odagmia - 10, Tetisimulium - один, Cleitosimulium - один, Archesimulium - два, Argentisimulium один, Simulium - шість видів [23].

Висновки та перспективи подальшого дослідження. Дослідження мошок Українських Карпат триває понад 60 років. За цей період науковці встановили видовий склад симуліїд окремих територій та подали зведений список видів для регіону в цілому. Згідно з останніми даними симуліїдофауна нараховує 45 видів із 14 родів. Науковці розкрили окремі аспекти біології й екології різних фаз розвитку цих комах в умовах високогір'я. Проте за сучасних темпів розвитку суспільства та зміни екологічної ситуації в регіоні певною мірою залишаються відкритими питання уточнення видового складу територій, які зазнали значного антропогенного пресингу, і природоохоронних об'єктів, а також комплексного біоекологічного дослідження мошок Українських Карпат.

\section{Джерела та література}

1. Ковбан В. 3. Изучение биологии мошек и мокрецов в предгорной зоне Ивано-Франковской области / В. 3. Ковбан // Ветеринария : респ. межвед. тематич. науч. сб. - Киев, 1967. - Вып. 11. - С. 73-77.

2. Ковбан В. 3. Изучение эпизоотологии онхоцеркоза крупного рогатого скота и разработка оздоровительных меропреятий против этого заболевания в условиях Прикарпатья и Полесья УССР : автореф. дис. ... канд. вет. наук / В. З. Ковбан. - М., 1967. - 24 с.

3. Ковбан В. 3. Случай симулиидотоксикоза крупного рогатого скота / В. 3. Ковбан // Ветеринария. 1966. - № 5. - С. 88-90.

4. Ковбан В. 3. Уничтожение преимагинальных фаз мошек и мокрецов в быстротекущих ручьях предгорий Карпат препаратами никохлорана и полихлорпилена / В. З. Ковбан // Инфекц. и паразитарн. болезни с/х животных. - М., 1963. - С. 153-161.

5. Панченко А. А Біорізноманіття України: естественноисторическое изучение семейства Мошек (Diptera: Simuliidae) / А. А. Панченко. - Донецк : ДонНУ, 2004. - 169 с.

6. Панченко А. А. К фауне мошек (Diptera: Simuliidae) верхнего басейна Днестра и Прута / А. А. Панченко, 3. В. Усова // Реф. ин-ция о законченных и.-и. раб. в вузах УССР. - Киев, 1976. - Вып. Х. C. 35 .

7. Панченко А. А. Фауна и зоогеографический анализ мошек (Diptera, Simuliidae) Предкарпатья / А. А. Панченко // VII Международный симпозиум по энтомофауне Средней Европы : тезисы докладов - Л., 1977. - C. 76-77.

8. Панченко А. Б. Мошки (Diptera: Simuliidae) массива «Чорногора» Карпатского биосферного заповедника / А. Б. Панченко // Биологические исследования на природоохранных территорий и биологических стационарах : тезисы докладов биост. ХГУ (Харьк. обл., Змиевский р-н, с. Гайдары, 16-19 сент. 1999 г.). Харьков, 1999. - С. 98-99.

9. Панченко А. Б. Мошки Украинских Карпат / А. Б. Панченко // V з’їзд Українського ентомологічного товариства : тези доп. (Харків, 7-11 верес. 1998 р). - К., 1998. - С. 123-124.

10. Панченко А. Б. О влиянии паразитов и врагов мошек (Diptera: Simuliidae) на их численность в Украинских Карпатах / А. Б. Панченко // Возбудители и переносчики паразитов и меры борьбы с ними : материалы Всесоюзн. конф. по паразитол. - Киев, 1988. - С. 149.

11. Панченко А. Б. О заражености куколок мошек грибом Celomycidium simulii в Карпатах / А. Б. Панченко, П. Н. Пергало // «Патол. членистон. и биол. средства борьби с вредными организмами» : тез. докл. Первой респ. науч. конф. - Канев, 1982. - С. 191-192.

12. Панченко А. Б. О заражености микроспоридиями мошек Угольско-Широколужанского массива Карпатского заповедника / А. Б. Панченко // X конференция Украинского общества паразитол. : материалы конф. - Киев, 1986. - Ч. 2. - С. 101.

13. Панченко А. Б. О зимовках мошек Закарпатской области / А. Б. Панченко // Исслед. по энтомол. и акарал. на Украине : тезисы докладов II съезда УЭО. - Киев, 1980. - С. 123-124.

14. Панченко А. Б. О некоторых трофических связях мошек (Diptera: Simuliidae) в Закарпатье / А. Б. Панченко // ІХ съезд ВЭО. - Киев, 1984. - Ч. 2. - С. 91-92.

15. Панченко А. Б. О питании личинок ручейников (Trichoptera) личинками мошек (Diptera: Simuliidae) в водотоках Украины / А. Б. Панченко, А. А. Панченко // Материалы научно-практической конференции паразитологов (г. Киев, Нац. аграр. ун-т, 3-5 ноября 1999 р.). - Киев, 1999. - С. 128-130. 
16. Панченко А. Б. О популяционной и экологической изменчивости личинок Boophthora erythrocephala De Geer (Diptera: Simuliidae) в водотоках Закарпатья / А. Б. Панченко // Двукрылые фауны СССР и их роль в экосистемах : материалы 3 Всесоюзного симпозиума диптерологов (Белая Церковь, 15-17 сент., 1982 г.). - Л., 1984. - Ч. 2. - С. 97-98.

17. Панченко А. Б. О фауне и биологии мошек (Diptera: Simuliidae) Карпатского заповеднка / А. Б. Панченко, 3. В. Усова // I Всесоюзный съезд паразитоценологов : тезисы докладов. - Киев, 1978. - Ч. 3. C. $112-113$.

18. Панченко А. Б. Об активности нападения и местах укрытий мошек в Закарпатской области / А. Б. Панченко // Х конференция УРНОП : тезисы докладов. - Киев, 1980. - Ч. 5. - С. 66-67.

19. Панченко О. Б. Аспект ландшафтного поширення фауни мошок (Diptera: Simuliidae) в Українських Карпатах / О. Б. Панченко, А. О. Панченко // Науковий вісник УжНУ. - Серія : Біологія. - Ужгород, 2001. - № 9. - С. 295-297.

20. Ремм Х. Я. Заметки по фауне кровососущих двукрылых Закарпатской области / Х. Я. Ремм // Доклады и сообщения Ужгородского государственного университета. - Серия : Биология. - Ужгород, 1957. Вып. 1. - С. 69-71.

21. Рубцов И. А. Фауна СССР. Двукрылые: мошки (сем. Simuliidae) / И. А. Рубцов. - М. ; Л., 1956. - Т. 6. Вып. 6. -859 с.

22. Сухомлін К. Б. До питання про поширення мошок (Diptera, Simuliidae) в басейні річки Теребля / К. Б. Сухомлін, О. П. Зінченко, В. С. Теплюк // Вісник Прикарпатського національного університету імені Василя Стефаника. - Серія : Біологія. - Івано-Франківськ : Гостинець, 2008. - С. 75-77.

23. Сухомлін К. Б. Фауна мошок родини Simuliidae Українських Карпат / К. Б. Сухомлін, О. П. Зінченко // Науковий вісник Ужгородського університету. - Серія : Біологія. - Ужгород, 2008. - С. 220-232.

24. Усова 3. В. Зональное распределение мошек (Diptera, Simuliidae) Украины / 3. В. Усова // Кровососущие двукрылые и х контроль. - Л., 1987. - С. 133-136.

25. Усова 3. В. О местах выплода мошек (Diptera: Simuliidae) Закарпатской области / 3. В. Усова, А. Б. Панченко // Паразитология. - 1973. - Т. VII. Вып. 6. - С. 541-544.

26. Шевченко А. К. Фауна и экология мошек (Diptera, Simulidae) Украины / А. К. Шевченко // Проблема паразитол. : тр. VI науч. конф. УРНОП. - Киев, 1969. - Ч. 2 - С. 197-199.

Теплюк Алла. История изучения мошек Украинских Карпат. Проанализировано современное состояние изучения мошек Украинских Карпат. Установлено, что исследования Simuliidae региона продолжаются более 60 лет. В 60-е годы XX в. В. 3. Ковбан исследовал медико-ветеринарное значение и методы борьбы с кровососущими видами Simuliidae. В 1969 г., по данным А. К. Шевченко, симулиидофауна региона насчитывала 11 видов. В 1973 г. З. В. Усова и А. Б. Панченко зарегистрировали в Украинских Карпатах 42 кровососущих вида и рассмотрели их биоэкологические особенности. В 1987 г. З. В. Усова уже отметила для региона 46 видов мошек. В 2004 г. А. А. Панченко обобщил результаты своих многолетних исследований и сведения других ученых, проанализировал систематические и синонимичные названия и сообщил, что симулиидофауна Украинских Карпат насчитывает 56 видов. В 2008 г. К. Б. Сухомлин провела ревизию собственных сборов и коллекционных фондов кафедр зоологии Восточноевропейского национального университета имени Леси Украинки и Донецкого национального университета и уточнила, что видовой состав мошек региона насчитывает 45 видов.

Ключевые слова: мошки, фауна, видовой состав, кровососы, Украинские Карпаты.

Alla Tepliuk. History of the Study Blackflies Ukrainian Carpathians. It has been analyzed the modern state of the study blackflies Ukrainian Carpathians. It has been established that the explore of Simuliidae region are continuing for over 60 years. In the 1960s, V.Z. Kovban explored medical-veterinary importance and methods of fighting bloodsucking species of Simuliidae. In 1969 simuliidofauna region totaled 11 species blackflies according to A. K. Shevchenko. In 1973 in the Ukrainian Carpathians Z. V. Usova and A. B. Panchenko registered 42 bloodsucking species and examined their especially of biology and ecology. In 1987 Z. V. Usova already noted 46 species of blackflies for the region. In 2004 A. A. Panchenko summarized the results of his many years of research and data to other scientists, analyzed the systematic names and synonyms, and said that simuliidofauna of Ukrainian Carpathians totaled 56 species. In 2008 K. B. Suchomlin made an audit of own fees and collection funds of the Department of Zoology of Lesya Ukrainka Eastern European National University and Donetsk National University, and clarified that the species composition of blackflies in the region totaled 45 species.

Key words: blakflies, fauna, species composition, bloodsuckers, Ukrainian Carpathians.

Стаття надійшла до редколегії 15.02 .2016 p. 